\title{
New Historicism
}

\section{Matt Hickling}

Brock University

\begin{abstract}
This article draws attention to the keyword "New Historicism" through its evolution from its antecedent "Historicism." Using the OED definition of both as a starting point, this article explains the development of New Historicism as an interpretive strategy in the study of history and literature. In keeping with the "keywords" mandate to examine conflicting and contested terms, I cite both Stephen Greenblatt's initial development of new historicism as an interpretive strategy and the subsequent critiques. In citing examples from popular culture and aspects of Canadian history, I demonstrate the utility of New Historicism and explain how it is distinct from historicism.
\end{abstract}

Keywords: historicism, new historicism, history

Matt Hickling graduated from the Master of Education Program at Brock University, with a specific focus on social and cultural contexts of education. He also has a graduate degree in Canadian history and teaches in the department of history at Brock University. His research interests include international geopolitics, diplomacy, and the manifestation of diversity in our multi-cultural Canadian society. He is also fascinated with the manner by which history is taught, and the process by which historical understanding can impact the contemporary interpretation of our increasingly globalized society.

Email:mh16ok@brocku.ca 
In January 2011 one of the most celebrated television programs in recent memory, Downton Abbey, brought history to millions of households. By hitting on exactly the right combination of real historical events of the early twentieth century, entwined with scandal, intrigue, romance and class and family dynamics, the series became a huge international success. Despite the fact that it is categorized as a "period drama" in the entertainment lexicon, and that historians might be quick to identify some factual inaccuracies, Downton Abbey's success was largely due to how it presented a compelling story grounded in the lives of upper- and lower- class individuals as they negotiated the seismic historical events of the period. In so doing, the television drama provided a fictional ground from which viewers could re-imagine and re-interpret historical events.

New Historicism stands as a new (the first recorded use was in 1972) interpretive strategy. The Oxford English Dictionary (OED, 2011) defines New Historicism as "a form of cultural analysis which examines the ways in which a cultural product (especially a literary text) interacts with and participates in its historical context, especially with reference to the power relations operating within the society of its time." Yet, as a relatively recent scholarly approach, New Historicism has been vulnerable to criticism. John Brannigan (1998) for instance, makes the case that New Historicism is not as new as it appears to be, arguing that Herodotus, with his emphasis on the stories of Greek heroes and citizens alike, might have been the first new historicist. The "old" historicists would likely disagree with this categorization, as Paul Cantor (1993) suggests that "the motto of the New Historicism seems to be 'I can connect anything with anything." Although this dismissive explanation minimizes the importance of the New Historicism, it does speak to the degree of resentment it engenders in its blurring of boundaries between history and literary criticism.

In the late nineteenth century, by way of Germany, historicism entered the vernacular of American literary scholarship. The OED defines it as "any of the various beliefs that social and cultural phenomena cannot be considered independently of their historical context." This manner of thinking dominated American academe through the mid-twentieth century. Its practitioners were constrained by notions of grand, sweeping narratives of history and it tended to prioritize the voices of what were known as Western colonial powers, that is stories of white, Anglo-European men and their technological accomplishments and territorial possessions. By the early 1980s, a movement now known as New Historicism sought to "breathe new life into canonical texts" (Kramer \& Maza, 2006) in an attempt to "reconceive history on the model of literature" (Cantor, 1993). Good literature conveys emotion to the reader, and if history is framed through this model, it too looks for a similar emotional response.

What New Historicism does is engage in the emphasis on power relations operating within the society of its time. That is, New Historicism consciously engages the idea that we inevitably read the past from the present. Several scholars (Prendergast, 1999; Sharma, 2014; Brannigan, 1998) note that there are distinct American and British camps of New Historicism, suggesting that it "rests on no single theoretical stance, [in] that it is a practise not a theory" (Maza, 2004; Greenblatt, 1987).

As the acknowledged initiator of New Historicism, one of Stephen Greenblatt's main arguments is that there is a real social world that is constantly being shaped and re-shaped by the texts it produces. Greenblatt and other scholars (Balkaya, 2014) support a transition away from historicism towards New Historicism because they feel that there is an emotional void that exists when historical events are disconnected from the reality within which they actually happened. They also champion women, children, people of colour, non-Christians, and other previously marginalized groups as essential components of the larger historical narrative. 
John Brannigan (1998) explains how New Historicism understands the stories of the past as society's way of constructing a narrative which unconsciously fits its own interests. Such power dynamics feature prominently in the work of Marxist thinkers, including Louis Althusser, who see history as the procession of stories favourable to the victor and literature as one of the institutions which participate in making state power and ideology familiar and acceptable to the state's subjects (Althusser, 1984 as cited in Brannigan, 1998). New Historicism builds on these approaches but scholars such as Greenblatt emphasize the use of the past as an "impetus for political struggle in the present, and make it clear that the discipline of literary studies is not removed from the sphere of politics" (Brannigan, 1998).

Generally speaking, Historicists are "traditional historians," who prioritize scholarly research, and eschew any reorganization of history that might diminish their own power or the importance of their subject. New Historicists are certainly scholarly, but they focus more on a history that is nuanced, imbued with emotion and written from the perspective of ordinary people (indeed, those often considered marginal) who are coping with extraordinary world-changing events. Ultimately, the shift from historicism to New Historicism emphasizes the relation between events and emotional response and informs the notion that such events are never to be considered neutral.

New Historicists typically make liberal use of historical anecdotes or material artefacts in order to inform, contextualize and illustrate historical concepts. Dismissed by some as "shoddy history" (Cantor, 1993), investment in the anecdote is a key New Historicist move, from a methodological point of view (Prendergast, 1999). Anecdotes enable us to see the personal in the context of the political. They enable history to be re-situated in the context of contemporary parlance; for example, in the early 1980s there was a distinct political shift to the right with the election of Margaret Thatcher in Britain and Ronald Reagan in the United States. In both cases, New Historicists encouraged readers to revisit interpretations of classic works by Shakespeare, Webster, Wordsworth and Dickens, among others, and re-read them in the context of their contemporary situation (Brannigan, 1998).

There has been a recent renewed sense of interest in dystopic fiction, such as George Orwell's (1949) Nineteen Eighty-Four and Sinclair Lewis' (1936/2014) It Can't Happen Here, owed in no small measure to the election of Donald Trump in 2016. In the context of education, the nuanced readings of New Historicism have had some impact on the more traditional historicism used in secondary-school textbooks. Notorious for grand, sweeping narratives, generations of students learned that, for example, that there were three causes of the First World War and that John A. MacDonald was a great nation builder (Brown, 2012). Those were the facts and thus were taught as history, as a linear progression of events. New Historicists however, moving from the premise that there is more to the story, investigate MacDonald, a king of back-room deals in the nineteenth century, and Louis Riel and his mythical status amongst the Metis and the people of Manitoba (Brown, 2012).

New Historicists also focus on the impact of emotion in relation to events. In the context of MacDonald's National Dream, for example, the completion of the Trans-Continental Railroad is taught as the salient historical event. Individual stories of the Chinese migrant labourers - many of whom lost their lives - have not been regarded as part of the story. Historicists argue that it is essential that we prioritize the importance of Craigellachie as part of the larger narrative of Canadian history. New Historicists focus their attention on the migrant labourers and how they felt in the late nineteenth century.

In the context of First Nations history in Canada, New Historicists focus their attention not on a top-down analysis that tends of pervade history textbooks, but rather on the impact of the colonial 
encounter on Indigenous populations. Stories, anecdotes, informal musings, comments about the government and those made between friends are important aspects of history that invoke responses to the events that have made up the Canadian history curriculum.

Fundamentally, New Historicists emphasize the notion that historical values change over time, whereas historicists prioritize the immutable and unchangeable notion of historical facts. Students often decry history as nothing more than a process by which they memorize facts, and partially for this reason, Canadian history is not considered a popular subject in school. Anecdotally speaking, students complain that our history is dull, uninteresting and static, although CBC productions such as "Canada: A People's History" and "Canada: The Story of Us" re-contextualize the narrative and promote the idea that our history is exciting, relevant and applicable - if we consider it beyond the traditional nature to which many of us are accustomed.

Innovative history teachers, as they implement the lessons of the New Historicists, engage with their students and show them that history can be taught and understood from several different platforms. In the process, students can to see themselves in such stories, particularly if they identify as part of the minority in terms of race, class, gender, or culture. This is poignantly relevant in modern Canada, where we prioritize multiculturalism and celebrate our inclusive educational community. Ultimately, if students can find value and resonance in their educational experience, they are more likely to understand who they are and fully appreciate their place in the world. 


\section{References}

Balkaya, M. (2014). Basic principles of New Historicism in the light of Stephen Greenblatt's Resonance and Wonder and Invisible Bullets. European Academic Research, 2(5), 7068-7078.

Brown, C. (2012). The illustrated history of Canada. Montreal: McGill-Queen's University Press.

Brannigan, J. (1998). New Historicism and cultural materialism. New York: St. Martin's Press.

Cantor, P. (1993). Stephen Greenblatt's new historicist vision. Academic Questions, 6(4), 21-36.

Greenblatt. (1987). Towards a poetics of culture. Southern Review. 20(1), 3-15.

Kramer, L. \& Maza, S. (2006). A companion to western historical thought. Malden, MA: Blackwell Publishing.

Lewis, S. (1936/2014). It can't happen here. New York: Penguin Publishing Group.

Maza, S. (2004). Stephen Greenblatt, New Historicism, and cultural history, or, what we talk about when we talk about interdisciplinarity. Modern Intellectual History, 1(2), 249-265.

New Historicism. (2011). In Oxford English dictionary ( $3^{\text {rd }}$ ed.). Retrieved from http://dictionary.oed.com

Orwell, G. (1949). Nineteen eighty-four. New York: Penguin Publishing Group.

Prendergast, C. (1999). Circulating representations: New Historicism and the poetics of culture. SubStance, 28(1), 90-104

Sharma, R. (2014) New Historicism: An intensive analysis and appraisal. Indian Review of World Literature in English, 10(2), 1-11. 